\title{
Sustainable Cereal Straw Management: Use as Feedstock for Emerging Biobased Industries or Cropland Soil Incorporation?
}

\author{
Lovisa Björnsson $^{1}$ (D) Thomas Prade $^{2}$ (D)
}

Received: 22 March 2020 / Accepted: 1 March 2021 / Published online: 12 March 2021

(c) The Author(s) 2021

\begin{abstract}
Sustainability goals regarding biobased chemicals and fuels can lead to increased demand for cereal straw, which could lead to undesirable effects on soil organic matter (SOM) content. The aim of this study was to evaluate the effects of removing straw on SOM, using a life cycle approach based on agricultural statistics and soil carbon modelling. This regional evaluation in southern Sweden showed that the general restrictions on straw removal recommended in many European studies, with demands on the incorporation of at least half of the aboveground straw, is not an efficient means of SOM preservation. Unrestricted straw removal in combination with the cultivation of intermediate crops leads to a much higher SOM build-up. Such measures will increase the availability of removable straw 2.5 times, at little extra cost. The findings of this study demonstrate the necessity of regional evaluation, taking new findings on the impact of straw incorporation on SOM into consideration. This is important for both regional emerging biobased industries, where unnecessary restrictions on straw removal might hamper the development of new production pathways, and for future sustainability in agriculture, where well-intended but inefficient SOM preservation strategies might hinder the implementation of more efficient measures.
\end{abstract}

\section{Graphic Abstract}

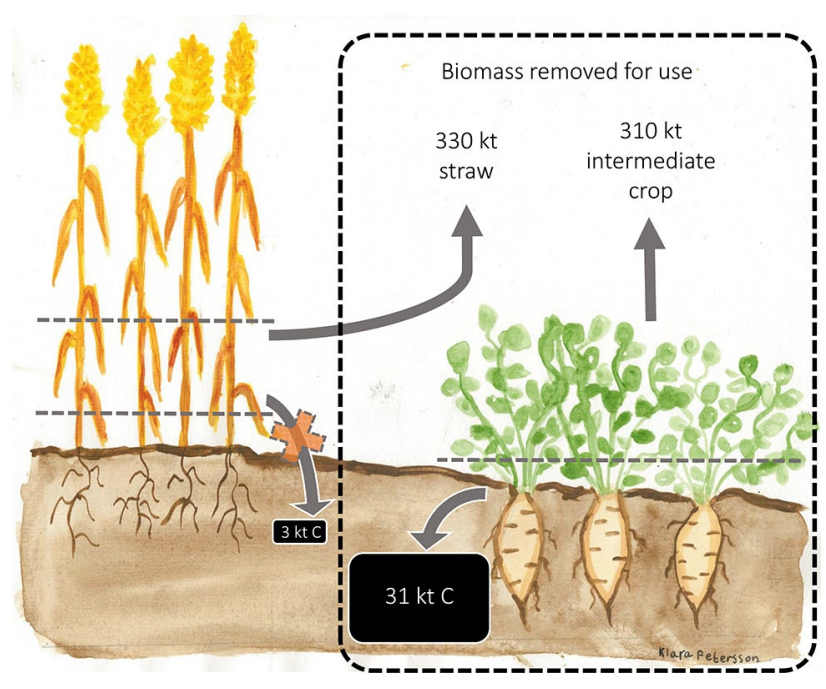

Keywords Soil carbon · Greenhouse gas emissions · Intermediate crops · Cover crops · Conflicting sustainability goals

Lovisa Björnsson

lovisa.bjornsson@miljo.lth.se

Extended author information available on the last page of the article 


\section{Statement of Novelty}

Cereal straw is an abundant agricultural by-product in Europe. This study provides new knowledge on straw availability and the potential impact of large-scale straw removal on organic matter in agricultural soils in a regional investigation in Sweden. General straw removal restrictions are currently applied in the EU, with the aim of preserving soil organic matter. However, the findings of this study show that soil incorporation of straw is not generally efficient for organic matter build-up. Restrictions on straw removal can be unnecessary, and may prevent the implementation of more efficient measures for organic matter preservation. We suggest cultivation of intermediate crops as an alternative approach that would allow both unrestricted straw removal and contribute to soil organic matter build-up, with little impact on the cost of straw as feedstock for biobased industries. The conflicting sustainability goals between straw removal and use and soil incorporation can thus be avoided.

\section{Introduction}

Cereal straw has attracted considerable attention as a globally available feedstock that can be used for the biobased production of chemicals and fuels through various technical processes and valorization pathways [1-6]. In Europe, wheat straw has been identified as the most promising currently unused agriculture-based feedstock for the biobased chemicals industry [6]. Concern for climate change is the main driving force behind the transition from fossil-based to biobased feedstock, and ensuring low greenhouse gas (GHG) emissions is a key aspect in the production chain. According to the revised EU Renewable Energy Directive (EU REDII), future biobased fuels for road transport are required to have $65 \%$ lower GHG emissions than fossil fuels [7]. It has been argued that an increasing number of biomass-based products will have to meet similar demands on climate performance in the future [8]. Reliable assessments of straw availability and GHG emissions will thus be required to make straw an attractive feedstock in emerging biobased industries.

On the other hand, the European Environment Agency published an assessment in 2010, showing that about $45 \%$ of the mineral soils in Europe had a low or very low organic carbon content (0-2\%) [9]. A follow-up survey shows that the soil organic matter (SOM) in mineral soils used as cropland in Europe has further decreased with on average $2.5 \%$ [10]. Decreasing SOM may decrease crop yields and productivity $[11,12]$ and can give problems with soil compaction and ensuing crop failure due to standing water on high-clay-content soils [13]. Declining SOM content as a threat to soil fertility, and thereby food security, has thus become a topic of active scientific research during the past decade [14]. Furthermore, SOM degradation leads to the transfer of carbon from the large soil carbon pool to the atmosphere as carbon dioxide, contributing to climate change. It has been estimated that topsoil in the EU stores $79 \mathrm{Gt}$ carbon [14]. Agricultural practices that preserve carbon in the form of SOM, or even sequester carbon by increasing SOM, are thus important. In the EU, cereal production dominates the cropland, amounting to $72 \%$, or 57 million ha, in 2019 [15]. The link between SOM and sustainable cereal straw management is that in regions with intensive cereal cultivation and little livestock, soil incorporation of cereal straw might be the only measure taken to maintain the organic matter in soil [16]. SOM is comprised of decomposed residues of biomass and the continuous addition of new biomass is a prerequisite for maintaining SOM levels. Soil incorporation of crop residue such as straw can also have other positive impacts as increased nutrient retention and availability, decreased susceptibility to erosion and enhanced water capacity [17]. However, straw incorporation also contributes to spreading of pathogens, and removal of cereal straw in autumn would be the best practice for reducing the risk of a Fusarium spp. infection [18].

This highlights the contrasting goals for sustainable cereal straw management, removal and use as feedstock for the emerging biobased industries on one side, and soil incorporation with the aim of preserving or even increasing SOM on the other side. The decline in SOM in EU agricultural soils is high on the agenda and restrictions on straw removal have been suggested as a means of ensuring sustainable SOM levels. Recommendations in European studies range from soil incorporation of $50-67 \%$ of the straw [6, 19-21]. Such general removal restrictions impact the straw availability for use in future biobased industries. In one study including 10 EU countries, the annual amount of cereal straw not currently used was estimated to be 107 million t dry matter (DM), but a recommendation of soil incorporation of 91 million t DM (corresponding to $60 \%$ of the straw) left only 16 million t DM straw available for emerging biobased industries [20]. Similar restrictions were applied in two projects mapping the agricultural biomass in Europe, where the aim was to support the future sustainable delivery of non-food biomass for a resource-efficient bioeconomy [22, 23]. Dees et al. [22] estimated the sustainable harvestable potential of cereal straw in the EU28 to be 120 million t, after applying removal restrictions to maintain SOM. However, current use was not subtracted. Gurria et al. [23] estimated that the total current use of crop residues (manly cereal straw) in the EU28 was 100 million $\mathrm{t}$, and that another 10 million $\mathrm{t}$ would 
be available for use in emerging biobased industries without affecting soil ecosystem services, such as fertility maintenance and SOM conservation. The straw availability after applying such general removal restrictions is thus reduced to only a small share of the harvestable straw amounts.

In the studies described above, it was assumed that straw removal exceeding recommended restrictions of 50-67\% soil incorporation of straw would result in a decrease in SOM. This is assumed to not only result in a direct release of carbon to the atmosphere, but also to reduce crop yields which, in turn, may displace crop production, leading to land conversion elsewhere. This is referred to as indirect land use change, which can be recalculated to GHG emissions that are attributed to the removed straw [24]. Such a GHG emission penalty has, for example, been calculated for an assumed removal of 20.5 million $t$ straw for European ethanol production [21]. One third of this straw was assumed to originate from regions with unsustainable straw removal, which was defined as removal of more than $33-50 \%$ of the cereal straw. This was assumed to lead to a decrease in SOM, and subsequent reductions in crop yields, and also to compete with straw use in the livestock sector. This, in turn, was calculated to correspond to a GHG emission penalty of $96 \mathrm{~kg} \mathrm{CO}_{2}$ equivalents $\left(\mathrm{CO}_{2} \mathrm{eq}\right)$ per ton straw [21]. In the EU REDII, on the other hand, the straw is categorized as a residue and assigned no burden from the emissions related to cultivation [7]. This means that when the GHG emissions of a straw-based biofuel is calculated, removing the straw from the field is seen as having zero GHG impact $[25,26]$. These conflicting messages on sustainability and GHG emissions from straw management thus strongly effect both estimations of straw availability and the view on GHG emission of using straw as feedstock, which can lead to uncertainty among emerging biobased industries planning the commercial utilization of straw as feedstock.

The uncertainty falls back on the good intention of restricting straw removal to avoid losses of SOM. However, the benefits of straw incorporation on SOM have recently been questioned. The contribution of organic matter to SOM is estimated by using models based on both short-term degradation tests and long-term field experiments for different types of organic matter input. In Sweden, the Introductory Carbon Balance Model (ICBM) is used for the national reporting of soil carbon changes in arable land [27]. This model, already when introduced, was based on the finding that root biomass contributed a higher share of long-term stable SOM than aboveground biomass. However, since the model was first introduced, long-term field experiments have been re-evaluated, and straw incorporation has been shown to have even less, or even no, impact on SOM in some regions/soil types [28-30]. Aboveground biomass incorporation has been shown to generally have less effect on SOM than previously thought, while the contribution of the root biomass has been increased [29-31]. Similar re-evaluations based on findings in long-term field experiments have been performed also for other countries/regions in for example the UK and the US [32-34]. Based on these findings, it has been suggested that the use of straw to replace fossil-based feedstock could be more beneficial from a climate perspective than its incorporation into the soil $[26,30]$. However, findings regarding the low cereal straw SOM contribution for some regions are not yet integrated in the models mentioned above, where straw removal restrictions and GHG penalties based on assumptions of SOM losses following straw removal, are assumed to be generally applicable across Europe [21-23].

The overall aim of the current study was to highlight the conflicting sustainability goals of straw removal and use, and soil incorporation for SOM preservation. The novelty of the study was the application of regional findings on SOM impacts of soil incorporation of straw, and the comparison to general straw removal restrictions. In addition, the cultivation of intermediate crops was investigated as an alternative strategy of SOM preservation. The current application of general straw removal restrictions is problematic for two reasons:

1. If straw incorporation is an inefficient method of SOM preservation, the current recommendations regarding straw removal restrictions and soil incorporation could hinder the implementation of more efficient SOM preservation measures. The cultivation of intermediate crops is one such measure.

2. Straw could be an important renewable feedstock for emerging biobased industrial production of materials and fuels, but removal restrictions could hinder the commercialization of these processes due to uncertainties regarding feedstock availability and sustainability.

The point of departure in the current study was that the conservation of SOM is a key aspect in future sustainable agriculture. Thus, SOM must be addressed in relation to straw removal, and aspects such as current straw demand and assumptions on removal restrictions in favour of soil incorporation must be taken into account by an industrial user to ensure sustainable production. At the same time, in the shaping of such removal restrictions the assumption that straw incorporation gives a high contribution to SOM has not yet been questioned. Detailed regional sustainability assessments are therefore necessary. The objectives were to evaluate the following aspects related to the sustainability of straw soil incorporation or removal in four Swedish cereal production areas: 
Fig. 1 Map showing the areabased potential of harvestable winter wheat straw in southern Sweden per year (annum, a). The area of the circle diagrams is proportional to the annual harvestable wheat straw amounts for the four main cereal production areas (PA1PA4). The straw is divided into the fractions currently used, the removable fraction and the share that should be incorporated in soil when a removal restriction is implemented

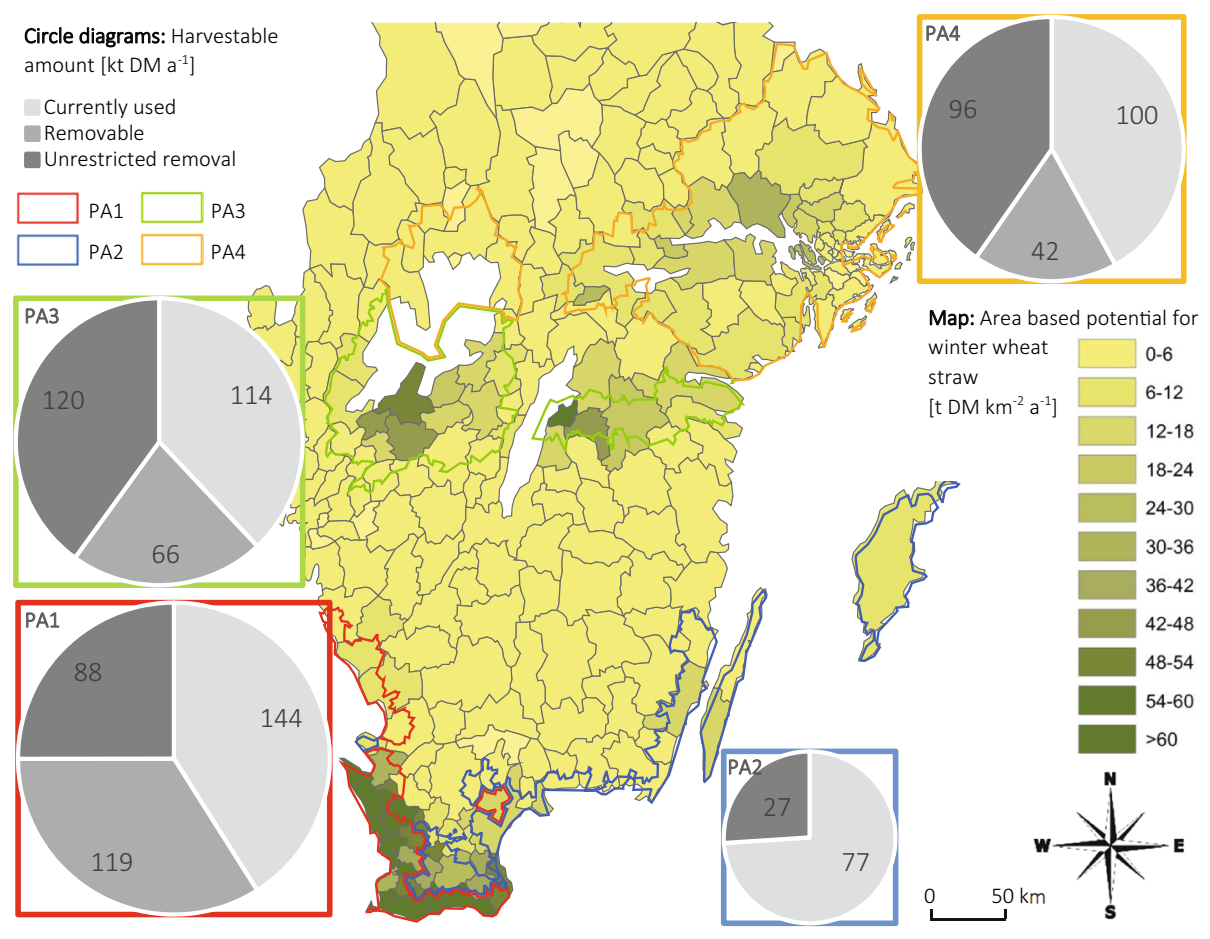

(i) To quantify regionally available amounts of straw, current use and removal restrictions, and to compare to restrictions in EU projects \& models,

(ii) To evaluate the effects of ignoring currently recommended straw removal restrictions on SOM and the introduction of an alternative SOM preservation strategy using cultivation of intermediate crops, and finally,

(iii) To quantify GHG emissions and the cost of straw assuming different removal strategies from an industrial user perspective.

\section{Methods}

\section{Study Regions}

One of the objectives of this study was to study regional conditions on a detailed level for the supply of straw as feedstock to biobased industries. This study is focused on agricultural production in southern Sweden, a cold climate region located between $55^{\circ}$ to $60^{\circ} \mathrm{N}$ and $12^{\circ}$ to $19^{\circ} \mathrm{E}$ [35], contributing $2 \%$ to cereal production in the EU in 2019 [36]. Four Swedish production areas in this region (PA1-PA4, Fig. 1) with varying cereal production, varying competing straw demands and different geographic and biological conditions influencing SOM were evaluated in detail. The study was limited to winter wheat cultivation and yields. Winter wheat is the dominating cereal in the region, and the four selected production areas covered, on average, $96 \%$ of the Swedish winter wheat cultivation area during the period 2012-2016 [37]. Agriculture in these production areas is dominated by crop rotation with annual crops, mostly cereals, leading to a high risk of decreasing SOM [38, 39]. The threat of decreasing SOM is addressed in Sweden, for example, in the National climate policy action plan, which states that methods of increasing carbon storage in arable land should be promoted [40]. In a recent survey covering the Nordic countries, cereal straw incorporation was pointed out as one such method [41]. The four production areas evaluated had different general recommendations regarding straw removal restrictions, and this and other features of these areas is outlined in this following sections.

\section{Straw}

The amount of harvestable straw was calculated by subtracting non-harvestable aboveground straw (stubble, straw not removable due to weather conditions, etc.). Recommendations for removal restrictions based on national expert opinions on straw soil incorporation requirements were then implemented [42], giving a total share of straw recommended for soil incorporation of $44-56 \%$ in the investigated region. This is in line with the general recommendations on straw soil incorporation (50-67\%) suggested to be necessary to avoid SOM impacts in several European studies [21, $43,44]$. The amounts of straw available for removal and commercial use were quantified with and without consideration of removal restrictions, and the effect of ignoring the removal restrictions on SOM was evaluated. 
Table 1 Agricultural data on cereal and straw yields and straw use

\begin{tabular}{lllll}
\hline Production area & PA1 & PA2 & PA3 & PA4 \\
\hline Straw yield [t DM ha $\left.^{-1} \mathrm{a}^{-1}\right]_{\text {. Theoretical above ground potential }}^{\mathrm{a}}$ & 5.06 & 4.21 & 4.06 & 3.56 \\
Straw yield [t DM ha $^{-1} \mathrm{a}^{-1}$ ]. Harvestable potential $^{\mathrm{b}}$ & 3.76 & 3.13 & 3.02 & 2.65 \\
Removal restriction, share of harvestable potential [\%] $^{\mathrm{c}}$ & 25 & 26 & 40 & 40 \\
Currently used, share of harvestable potential [\%] $^{\mathrm{d}}$ & 41 & 76 & 38 & 42 \\
\hline
\end{tabular}

${ }^{a}$ The corresponding winter wheat yields calculated as 5-year average ranged from 4.6 to 6.6 t dry matter (DM) ha ${ }^{-1}$, which can be compared to the average yield of common wheat in 2011-2015 in the EU of 5.0 t DM ha ${ }^{-1}$ [36]. Theoretical straw potential was calculated using a straw:grain ratio of 0.57 on DM basis [47], since ratios used in European studies [19, 20] have been shown to overestimate the amounts of straw under Swedish cultivation conditions. A carbon content of $45 \%$ of the DM was assumed [29]

b $26 \%$ of the theoretical potential was estimated to be non-harvestable stubble based on $20 \mathrm{~cm}$ stubble and a total straw length of $78 \mathrm{~cm} \mathrm{[48]}$

${ }^{c}$ Expert opinions on removal restrictions[42]

${ }^{\mathrm{d}}$ Regional competing use such as animal feed, bedding material or solid fuel, of which $68 \%$, on average, was used for animal bedding [45, 49]
Data on wheat yields, amounts of straw and competing use were collected from national agricultural statistics for the four production areas PA1-PA4 $[36,45,46]$ and aggregated as 5-year average for the years 2013-2017 on PA-level as described by Lantz et al. [25]. Data are summarized in Table 1 together with the regional recommendations regarding straw removal restrictions. The straw currently used for other purposes such as animal feed, bedding material or solid fuel was subtracted from the harvestable straw fraction [45]. The harvestable amount of straw remaining was considered to be removable without impact on SOM and market restriction. The scenarios where only this straw fraction is assumed to be removed and used are denoted removable in the results. In addition, results are presented for a scenario when removal restrictions were ignored and also this straw fraction was removed and used. This scenario is named unrestricted removal in the results.

It was assumed that all harvestable straw was collected and removed from an individual field, so a removal restriction of, for example, $25 \%$ was implemented as the removal of all harvestable straw three out of four years. Nutrients removed with the straw were assumed to be fully compensated for by mineral fertilizer addition, affecting both costs and emissions [50]. It was assumed that no compensation was paid to the farmer, and the straw cost calculation thus includes only costs and excludes profit. Nitrogen $(\mathrm{N})$, phosphorus $(\mathrm{P})$ and potassium $(\mathrm{K})$ content in the straw were assumed to be $6.6,0.6$ and $9.2 \mathrm{~kg}(\mathrm{t} \mathrm{DM})^{-1}$, respectively in the whole region (based on nutrient content for wheat straw as average for 73 database entries [51]).

\section{Intermediate Crops}

Intermediate crops cultivated after the harvest of cereals and before the next main crop, also called catch crops or cover crops, have been identified as important in SOM build-up in long term-field experiments $[52,53]$. Therefore, the cultivation of an intermediate crop (IC) once every two years of winter wheat cultivation was evaluated as an alternative strategy to SOM build-up through soil incorporation of straw. Different IC could be suitable for this purpose, but the study was limited to assessing the impacts of implementing oilseed radish (Raphanus sativus L.) as a model IC. We have done so in all four production areas, although it might be unsuitable in crop rotations including rapeseed (mainly occurring in PA1). Other IC yielding similar large amounts of biomass (and carbon) exist, but have not been further studied. Oilseed radish was assumed to be possible to include in the crop rotation after early food potatoes (17\% of total food potatoes; [54]), peas for processing and cereals including winter rye, winter barley, spring barley and winter wheat. When cereals were the preceding crops, it was also assumed that IC cultivation would take place only every four years, i.e. prior to a spring-sown crop such as sugar beet [24]. Harvestable IC biomass yields were assumed to be $3.0 \mathrm{t} \mathrm{DM} / \mathrm{ha} / \mathrm{a}$ for a growing period of 90 days between IC sowing and harvest [55]. This biomass yield was then adjusted accounting for two effects: (a) IC biomass yields were assumed to drop linearly from $3.0 \mathrm{t} \mathrm{DM} / \mathrm{ha}$ at the southernmost of Sweden (PA1) to 20\% lower at the northernmost point of the region (PA4); and (b) the number of days in the growing period was assumed to be influenced by typical harvest dates for the main crop and the latest harvest date of the IC, as presented in Table 2. Yields were estimated on a municipality resolution as described by Prade et al. [24] and then aggregated for each production area. The resulting biomass yield estimates are well within the range of earlier reported yields for oilseeds radish under similar conditions of a temperate humid climate [56, 57]. Environmental compensation amounting to $€ 150 \mathrm{ha}^{-1}$ is currently awarded for IC cultivation without fertilization in regions sensitive to nitrogen leakage, which is the case in all four production 
Table 2 Agricultural data for the intermediate crop

\begin{tabular}{lllll}
\hline Production area & PA1 & PA2 & PA3 & PA4 \\
\hline IC yield $\left[\mathrm{t} \mathrm{DM} \mathrm{ha}^{-1} \mathrm{a}^{-1}\right]^{\mathrm{a}}$ & $2.5(2.0-2.9)$ & $2.3(2.0-2.9)$ & $1.8(1.6-2.0)$ & $1.5(1.3-1.9)$ \\
IC growing period (days) $^{\mathrm{b}}$ & $69-124$ & $63-124$ & $58-101$ & $50-97$ \\
IC harvest/soil incorporation date & $17-19 / 10$ & $13-20 / 10$ & $9-11 / 10$ & $4-9 / 10$ \\
$\mathrm{IC}_{\text {carbon contribution }\left[\mathrm{t} \mathrm{C} \mathrm{ha}^{-1} \mathrm{a}^{-1}\right]^{\mathrm{c}}}$ & $1.1 / 1.3$ & $1.1 / 1.2$ & $0.8 / 0.9$ & $0.7 / 0.8$ \\
\hline
\end{tabular}

${ }^{a}$ Average yield of the harvestable part of the above ground biomass. Numbers in bracket present the data range

${ }^{b}$ Depending on the harvest date of the preceding crop and the IC

${ }^{\mathrm{c}}$ Referring to harvestable biomass/stubble and root biomass areas in the current study [58]. When IC cultivation costs and emissions are presented per $\mathrm{t}$ DM straw they have been divided by all removed straw (including the straw currently used for other applications).

The total amount of aboveground biomass (harvestable biomass $+10 \mathrm{~cm}$ stubble) and root biomass were estimated using a harvestable biomass:stubble ratio of 1.82 and an aboveground:belowground ratio of 4.3 , in order to transform the harvestable amount of IC biomass to soil organic matter (SLU; unpublished field experimental data). Root exudates were assumed to correspond to $65 \%$ of the root biomass and the carbon content was assumed to be $45 \%$ in all plant parts [29]. Resulting estimates of carbon accumulation in the harvestable biomass are yield-proportional to earlier reported values [57].

\section{Soil Organic Matter}

In line with the assumptions in European models of straw removal, adherence to a removal restriction is assumed to be sustainable in the sense that it has no effect on SOM [21, 43]. In the scenarios with unrestricted removal, the negative impact on SOM content was calculated. Georeferenced data on soil properties in the areas investigated were used, and SOM loss due to mineralization was modelled using the Introductory Soil Carbon Balance Model (ICBM) [27]. The ICBM simulates the soil organic carbon (SOC) content of soils based on carbon additions and mineralisation processes for carbon and is used for e.g. the Swedish annual GHG emission inventory [59]. The model was calibrated using data from long-term experiments located within the production areas. Each dataset contained data from 49 to 53 years on crop yield and manure added as well as SOC content determined at distinct intervals. From the crop yield data, crop residue amounts were estimated using relations between harvested product (grains etc.) and total aboveground biomass as well as aboveground to belowground biomass yield ratios. Carbon content of crop DM was assumed to be $45 \%$ [29] and root exudates (extra-root residues) were assumed to correspond to $65 \%$ of root residues [60]. The first-order reaction coefficient of the old carbon pool was used as a variable to fit the modelled to the measured SOC data by maximising the average coefficient of determination $\left(\mathrm{R}^{2}\right)$ of 32 datasets. The model was calibrated for each production area using data from long-term field experiments. The model parametrization used is presented in Table 3 . Humification coefficients of 0.15 for aboveground biomass and 0.35 for root biomass were used as a simplified estimate of the stable carbon contribution to SOM [25]. The humification coefficient for aboveground biomass was corrected for clay content, as suggested by Poeplau et al. [30]. The greater efficiency of stable carbon formation of belowground biomass was earlier attributed to the higher efficiency of the rhizosphere microbial community [61]. Since we found no indications of an effect of the clay content of soil on the humification coefficient for the belowground biomass, no such corrections were made for this part.

When cultivation of the IC was included, the resulting impact on SOM was estimated based on the removal of aboveground biomass minus $10 \mathrm{~cm}$ stubble (Table 2), and soil incorporation of the rest of the crop. This harvested biomass can potentially be used for other purposes such as for protein extraction or for biogas production, and the annual harvestable amount per production area is presented.

Build-up or degradation of SOM was presented as the corresponding release or sequestration of $\mathrm{CO}_{2}$. A simplified SOM balance was applied based on the difference between mean SOM mineralization and a stable fraction of added carbon based on the humification coefficients for root and straw biomass. When emissions due to changes in SOM are presented per t DM straw, they have been divided by all removed straw (including the straw currently used for other applications). No economic cost or income was attributed to an increase or decrease in SOM.

\section{Greenhouse Gas Emissions}

Greenhouse gas (GHG) emissions were calculated using an excel based tool for life cycle assessment based on the framework outlined in the ISO standard for life cycle assessment, with a functional unit of $1 \mathrm{t} \mathrm{DM}$ straw at the industrial facility gate [63]. Emissions of $\mathrm{CO}_{2}$ from fossil origin, 
Table 3 Production area (PA) specific data

\begin{tabular}{|c|c|c|c|c|c|}
\hline \multirow[t]{2}{*}{ Parameter } & \multirow[t]{2}{*}{ Unit } & \multicolumn{4}{|l|}{ Production area } \\
\hline & & PA1 & PA2 & PA3 & PA4 \\
\hline Land area & [ha] & 552,021 & 967,796 & $1,203,550$ & $2,963,151$ \\
\hline Share of arable land ${ }^{\mathrm{a}}$ & {$[\%]$} & $48.5 / 10.2$ & $30.1 / 11.1$ & $32.5 / 14.9$ & $19.5 / 22.1$ \\
\hline Share of winter wheat ${ }^{b}$ & {$[\%]$} & 8.8 & 2.4 & 11.3 & 10.7 \\
\hline Initial SOC content & {$[\%]$} & $1.77(1.25$ to 2.98$)$ & $1.97(1.25$ to 2.95$)$ & 2.06 (1.45 to 2.99$)$ & 2.08 (1.48 to 5.55$)$ \\
\hline Bulk density & {$\left[\mathrm{Mg} \mathrm{m}^{-3}\right]$} & $1.4(1.0$ to 1.6$)$ & $1.2(0.9$ to 1.6$)$ & $1.2(0.7$ to 1.6$)$ & $1.1(0.7$ to 1.2$)$ \\
\hline Clay content ${ }^{\mathrm{c}}$ & {$[\%]$} & $13.8(0.9$ to 31.7$)$ & $12.9(0.8$ to 38.7$)$ & $19.9(1.2$ to 64.1$)$ & $18.7(0.8$ to 69.4$)$ \\
\hline Annual mineralization ${ }^{\mathrm{d}}$ & {$\left[\mathrm{kg} \mathrm{C} \mathrm{ha}^{-1}\right]$} & $-364(-257$ to -611$)$ & $-316(-200$ to -472$)$ & $-422(-298$ to -613$)$ & $-270(-193$ to -722$)$ \\
\hline Reaction coefficient $\mathrm{e}^{\mathrm{e}}$ & {$\left[\mathrm{a}^{-1}\right]$} & 0.00888 & 0.00810 & 0.01024 & 0.00703 \\
\hline
\end{tabular}

Data used in the ICB model parametrization are given as mean values and range (min-max)

aproportion of arable land in total PA land area/proportion of PA arable land area in Sweden's total arable land area given as average of years 2013-2017 [37]

${ }^{\mathrm{b}}$ Proportion of total arable land in the PA given as average of years 2013-2017 [37]

${ }^{c}$ Used for estimating the impact on the humification coefficient $\mathrm{h}$ of the aboveground carbon input, using the relation: $\mathrm{h}=-$ $0.044+0.0036^{*}$ Clay[\%] [30]. Negative values are accounted for as in $\mathrm{h}=0$

${ }^{\mathrm{d}}$ Estimated using the ICBM based on a zero carbon input and average initial SOC content, clay content and a production area-specific mineralization rate

${ }^{\mathrm{e}}$ For the mineralisation of the old carbon pool. A reaction coefficient of $0.8 \mathrm{a}^{-1}$ was used for the young carbon pool [62]

Table 4 Life cycle greenhouse gas emission data

\begin{tabular}{lllll}
\hline Input & Emission & Unit & Refs. & Comment \\
\hline Diesel $^{\mathrm{a}}$ & 77.2 & $\mathrm{~g} \mathrm{CO}_{2}$-eq MJ-1 & {$[66]$} & $\begin{array}{c}\text { Average Swedish fossil diesel blend in 2018, } \\
\text { containing 23\% (vol.) biodiesel }\end{array}$ \\
Mineral N & 4.5 & $\mathrm{~kg} \mathrm{CO}_{2}$-eq $\left(\mathrm{kg} \mathrm{N}^{-1}\right.$ & {$[25]$} & Based on origin of import for Swedish use in 2016 \\
Mineral P & 2.3 & $\mathrm{~kg} \mathrm{CO}_{2}$-eq $\left(\mathrm{kg} \mathrm{P}^{-1}\right.$ & {$[67]$} & \\
Mineral K & 0.7 & $\mathrm{~kg} \mathrm{CO}_{2}$-eq $\left(\mathrm{kg} \mathrm{K}^{-1}\right.$ & {$[67]$} & \\
Seed $^{\mathrm{b}}$ & 0.73 & $\mathrm{~kg} \mathrm{CO}_{2}$-eq kg & {$[67]$} & \\
\hline
\end{tabular}

${ }^{\text {a }}$ To account for lubrication oils, an extra $4 \%$ on energy basis was added to the diesel use

${ }^{\mathrm{b}}$ Emission data for oilseed rape were used due to a lack of data for oilseed radish methane $\left(\mathrm{CH}_{4}\right)$ and nitrous oxide $\left(\mathrm{N}_{2} \mathrm{O}\right)$, were expressed as global warming potential (GWP) in carbon dioxide equivalents $\left(\mathrm{CO}_{2} \mathrm{eq}\right)$, using characterization factors on a 100 -year perspective [64]. The scenarios included inputs and emissions from in-field removal and transport to industrial straw processing facilities with two annual straw demands: 20000 t DM and $100000 \mathrm{t} \mathrm{DM}$. The direct effects of straw removal were included (nutrient loss and changes in SOM). Changes in $\mathrm{SOM}$ were expressed as $\mathrm{CO}_{2}$ emission or uptake, as appropriate, and included nitrogen release or sequestration using a C:N ratio of 10:1 [38]. Release or sequestration of $\mathrm{N}$ was recalculated to give $\mathrm{N}_{2} \mathrm{O}$ emission or avoided emission using the IPCC factor for field emissions of $0.01 \mathrm{~kg} \mathrm{~N}_{2} \mathrm{O}-\mathrm{N}$ $(\mathrm{kg} \mathrm{N})^{-1}$ [65]. Emissions from machinery manufacture were not included. The inventory data on need for nutrient compensation at straw removal are presented in section 'Straw'. The diesel demand for field operations, baling and straw transport, and the diesel and seed demand for IC cultivation are presented in section 'Economic Costs'. The emission data used are summarized in Table 4 and were average values for Swedish conditions 2017-2018.

\section{Economic Costs}

Feedstock production costs were assessed using the stepwise calculation method described by Lantz et al. [25], and are presented per $\mathrm{t} D M$ straw at the industrial facility gate. This calculation included all necessary machinery operation and production means. When Swedish cost data were used, an exchange rate of $€ 1=$ SEK 10 was applied.

It was assumed that the wheat straw was baled and transported to an industrial facility by truck-mounted self-loading trailers. Machinery costs were estimated from recommended hourly costs and corresponding machinery capacity, and the fuel demand was estimated based on typical consumption data from the same study (Table 5) [68]. The resulting 
Table 5 Machinery costs for straw removal and supply [68]

\begin{tabular}{|c|c|c|c|}
\hline Machinery & Specifications & $\begin{array}{l}\text { Capacity } \\
{\left[\mathrm{ha} \mathrm{h}^{-1}\right]}\end{array}$ & $\begin{array}{l}\operatorname{Costs}^{\mathrm{a}} \\
{\left[€ \mathrm{~h}^{-1}\right]}\end{array}$ \\
\hline \multicolumn{4}{|l|}{ Baling } \\
\hline Tractor & $150 \mathrm{~kW}$ & & 71 \\
\hline Bale press & $\begin{array}{r}\text { square bales, } \\
1.2 \times 1.3 \mathrm{~m}\end{array}$ & 6.1 & 132 \\
\hline \multicolumn{4}{|l|}{ Transport } \\
\hline Tractor & $200 \mathrm{~kW}$ & & 86 \\
\hline $\begin{array}{l}\text { Self-loading bale field } \\
\text { trailer }\end{array}$ & & 2.6 & 30 \\
\hline Truck with bale trailer & Self-loading & $3.3-3.6^{\mathrm{b}}$ & 178 \\
\hline
\end{tabular}

ancluding costs for driver and fuel

${ }^{b}$ Depending on transportation distance in the different production areas

energy demand and cost for field operations and straw baling was the same per unit straw removed for all production areas, and was $29 \mathrm{MJ}(\mathrm{t} \mathrm{DM})^{-1}$, and $€ 8.9$ (t DM) $^{-1}$ (machinery and fuel), respectively. The transport distance was calculated based on average straw availability in the region, assuming a circular area with the industrial facility at the centre [49, 69], and an annual straw demand at the industrial facility of $20000 \mathrm{t}$ DM. The increased transport requirement, if the straw demand was increased to $100000 \mathrm{t}$ DM per industrial facility, was also calculated. The corresponding transport distances, fuel demands and costs are given in Table 6 for different straw removal strategies.

Nutrients removed with the straw were assumed to be fully compensated for by mineral fertilizer addition. The costs of nutrients in the form of mineral fertilizer N, P and
Table 7 Machinery costs for intermediate crop production [68]

\begin{tabular}{llll}
\hline Machinery & Specifications & $\begin{array}{l}\text { Capacity } \\
{\left[\mathrm{ha} \mathrm{h}^{-1}\right]}\end{array}$ & $\begin{array}{l}\text { Costs }^{\mathrm{a}} \\
{\left[€ \mathrm{~h}^{-1}\right]}\end{array}$ \\
\hline $\begin{array}{l}\text { Seed bed preparation } \\
\text { Tractor }\end{array}$ & $200 \mathrm{~kW}$ & 86 \\
$\begin{array}{l}\text { Multicultivator } \\
\text { Sowing }\end{array}$ & $4 \mathrm{~m}$, disc, tine roller & 2.9 & 53 \\
Tractor & $120 \mathrm{~kW}$ & & \\
Seed drill & $4 \mathrm{~m}, 3300 \mathrm{~L}$ & 2.0 & 87 \\
\hline
\end{tabular}

${ }^{\mathrm{a}}$ Including costs for driver and fuel

$\mathrm{K}$ were assumed to be $€ 1.0 / \mathrm{kg}$, $€ 2.1 / \mathrm{kg}$ and $€ 0.8 / \mathrm{kg}$, respectively [70]. It was assumed that no compensation was paid to the farmer, and the straw cost calculation thus includes only costs and excludes profit.

The seedbed for the intermediate crop was assumed to be prepared in one pass by using a multipurpose cultivator and the intermediate crop was then assumed to be sown using a standard seed drill (Table 7) [68]. The harvestable share of IC is reported separately, and is not included in the IC SOM contribution, but neither harvest costs nor value of removed IC biomass is included in the economic assessment.

The total diesel demand for IC cultivation amounted to $948 \mathrm{MJ} \mathrm{ha}^{-1}$, and the seed demand was $15 \mathrm{~kg} \mathrm{ha}^{-1}$ in all four production areas in the investigated region. The cultivation costs were assumed to be the same for the whole region, and were 22 (diesel), 93 (machinery) and 60 (seeds) $€$ ha $^{-1}$. The environmental compensation of $€ 150 \mathrm{ha}^{-1}$ for unfertilized ICs was included in the IC cost calculations.
Table 6 Average one-way transport distance and corresponding fuel demand and cost for straw transport to the industrial facility in the four production areas with different assumptions on straw removal

\begin{tabular}{|c|c|c|c|c|c|c|c|c|c|}
\hline \multirow[t]{3}{*}{ Scenario } & \multirow[t]{3}{*}{ Production area } & \multicolumn{8}{|c|}{ Industrial feedstock demand } \\
\hline & & \multicolumn{4}{|c|}{$20000 \mathrm{t} \mathrm{DM} \mathrm{a}^{-1}$} & \multicolumn{4}{|c|}{$100000 \mathrm{t} \mathrm{DM} \mathrm{a}^{-1}$} \\
\hline & & PA1 & PA2 & PA3 & PA4 & PA1 & PA2 & PA3 & PA4 \\
\hline \multirow[t]{3}{*}{ Removable } & Transport distance $(\mathrm{km})$ & 17.6 & $\mathrm{n} / \mathrm{a}$ & 32.0 & 57.8 & 39.3 & $\mathrm{n} / \mathrm{a}$ & $\mathrm{n} / \mathrm{a}$ & $\mathrm{n} / \mathrm{a}$ \\
\hline & Fuel demand $\left(\mathrm{MJ}(\mathrm{t} \mathrm{DM})^{-1}\right)$ & 284 & $\mathrm{n} / \mathrm{a}$ & 377 & 504 & 370 & $\mathrm{n} / \mathrm{a}$ & $\mathrm{n} / \mathrm{a}$ & $\mathrm{n} / \mathrm{a}$ \\
\hline & Transport cost $\left(€(t \mathrm{DM})^{-1}\right)$ & 27.9 & $\mathrm{n} / \mathrm{a}$ & 36.8 & 49.0 & 36.1 & $\mathrm{n} / \mathrm{a}$ & $\mathrm{n} / \mathrm{a}$ & $\mathrm{n} / \mathrm{a}$ \\
\hline \multirow[t]{3}{*}{ Unrestricted removal } & Transport distance $(\mathrm{km})$ & 13.3 & 37.4 & 19.0 & 31.9 & 29.8 & $\mathrm{n} / \mathrm{a}$ & 42.6 & 71.4 \\
\hline & Fuel demand $\left(\mathrm{MJ}(\mathrm{t} \mathrm{DM})^{-1}\right)$ & 267 & 390 & 325 & 401 & 333 & $\mathrm{n} / \mathrm{a}$ & 419 & 558 \\
\hline & Transport cost $\left(€(t \mathrm{DM})^{-1}\right)$ & 26.5 & 38.3 & 32.1 & 39.3 & 32.8 & 55.7 & 41.0 & 54.3 \\
\hline
\end{tabular}

$n / a$ not applicable due to insufficient amounts of straw being available in the area 
Table 8 Harvestable amounts of intermediate crop (IC) per production area (PA)

\begin{tabular}{ll}
\hline Production area & $\begin{array}{l}\text { Amount } \\
\text { IC }[\mathrm{kt} \mathrm{DM} \\
\left.\mathrm{a}^{-1}\right]\end{array}$ \\
\hline PA1 & 117 \\
PA2 & 38 \\
PA3 & 89 \\
PA4 & 68 \\
\hline
\end{tabular}

The detailed assessment of the four production areas revealed that the total annual amount of removable straw that could be used in the bioeconomy in the region was 230 $000 \mathrm{t} \mathrm{DM} \mathrm{a}^{-1}$. This is under the assumption that no competition with current use (mainly for animal bedding) should occur and when the removal restriction is implemented. The straw harvested and currently used for mainly animal bedding was $440000 \mathrm{t} \mathrm{DM} \mathrm{a}^{-1}$, and this was excluded in all further calculations, so as not to compete with current
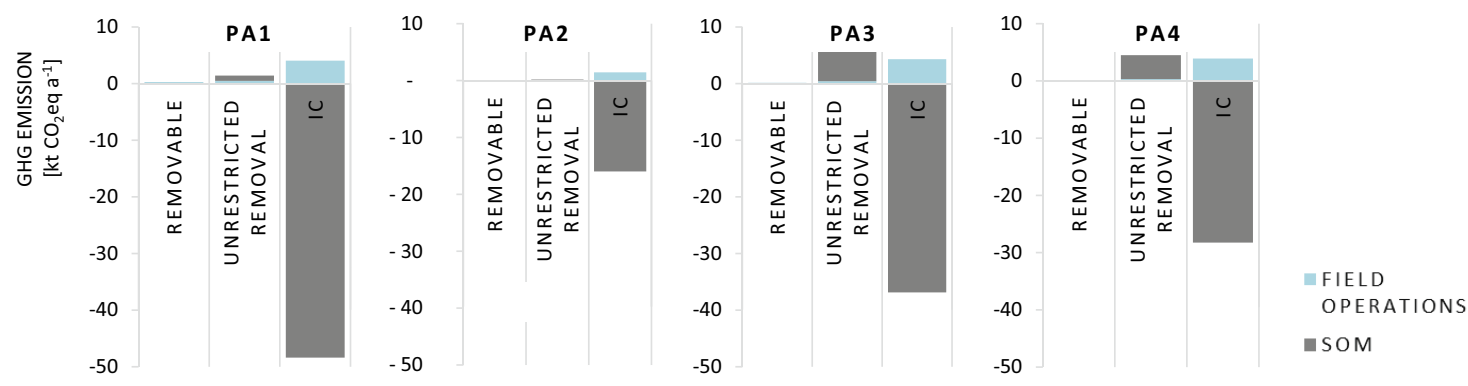

Fig. 2 Greenhouse gas emissions resulting from field operations and changes in soil organic matter (SOM) for the four investigated production areas (PA1-PA4), with different scenarios for straw removal and the cultivation of an intermediate crop (IC)

\section{Results and Discussion}

\section{Biomass Amounts}

The harvestable amount of winter wheat straw is presented as an area-based density for the whole region of Southern Sweden (Fig. 1) to enable comparison with a European survey where the straw potential for the same region ranged from 28 to $75 \mathrm{t} \mathrm{DM} \mathrm{km}^{-2} \mathrm{a}^{-1}$ [71]. ${ }^{1}$ The results presented in Fig. 1 illustrate the magnitude of variations even within a limited region, underlining the need for detailed assessments.

The four production areas chosen for more detailed assessment included two regions with a high straw density (PA1 and PA3) and two with a low (PA2 and PA4) (Fig. 1). These areas also had different levels of straw currently used for competing purposes and recommendations on removal restrictions. The area of the circle diagrams is proportional to the harvestable amount of straw in each production area, divided into straw share currently used, the removable amount (when consideration is taken to removal restrictions), and the share that is currently incorporated in soil when removal restrictions are implemented, so would only be harvested at unrestricted removal.

\footnotetext{
${ }^{1}$ Own correction of the unit given in the database, which was kt DM $\mathrm{km}^{-2} \mathrm{a}^{-1}$
}

use. The amount of harvestable straw that would be incorporated into the soil with removal restrictions was 330000 $\mathrm{t} \mathrm{DM} \mathrm{a}^{-1}$. This amount is included in the amount of straw removed in later calculations for the scenario unrestricted removal, when removal restrictions are ignored. The variation between the production areas is large, and in PA2 no straw would be available when current removal restrictions are applied. If IC were introduced, the harvestable amount of IC biomass in the whole region would be $310000 \mathrm{t} \mathrm{DM} \mathrm{a}^{-1}$. The annual IC amount per PA is shown in Table 8.

\section{Sustainability in Straw Removal}

\section{Effects on Soil Organic Matter}

The greenhouse gas emissions per production area resulting from field operations and changes in SOM are given in Fig. 2. The emission due to field operations is small in all production areas and amounts for the whole region to 0.6 $\mathrm{kt} \mathrm{CO}_{2} \mathrm{eq}$ per year in the removable scenario, and $1.3 \mathrm{kt}$ $\mathrm{CO}_{2} \mathrm{eq}$ per year in the unrestricted removal scenario. With unrestricted removal of straw, the loss of SOM for the whole region results in an annual $\mathrm{GHG}$ emission of $11 \mathrm{kt} \mathrm{CO}_{2} \mathrm{eq}$. The variation between the production areas is large, and $54 \%$ of this negative SOM impact is found in PA3, and 37\% in PA4. The variation is due to the varying amounts of straw removed and the soil properties, where high-clay-content 


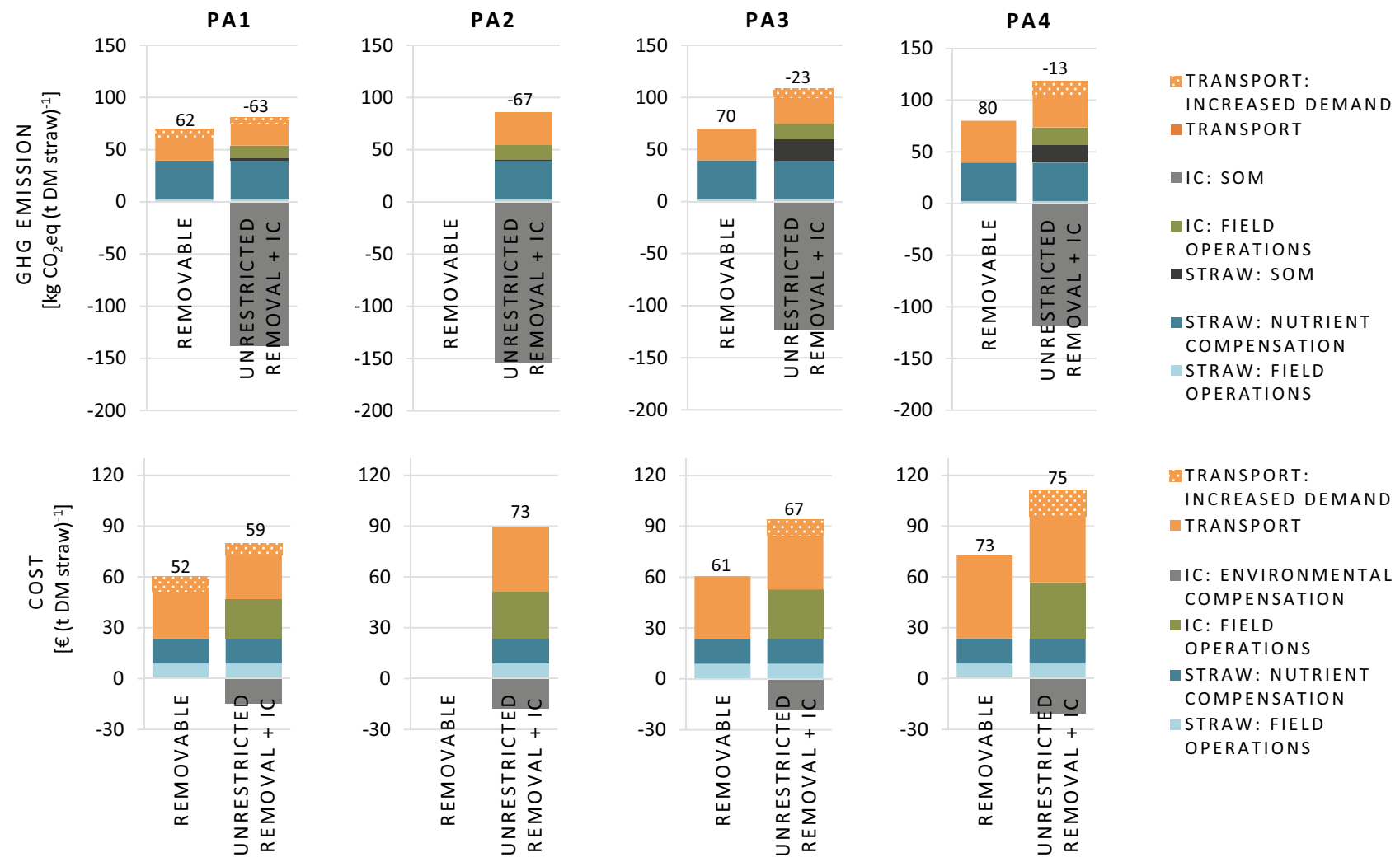

Fig. 3 Greenhouse gas emission and cost in the four production areas investigated (PA1-PA4) assuming different scenarios for straw removal and the cultivation of an intermediate crop (IC). The values above the bars include the impact of transport to a facility with

soils have the ability to retain and stabilize more of the carbon from aboveground biomass [30].

The alternative means of SOM preservation, the cultivation of IC, give an emission from field operations of $13.7 \mathrm{kt}$ $\mathrm{CO}_{2}$ eq per year for the whole region. IC cultivation was a successful strategy to compensate for negative SOM impacts of unrestricted straw removal in all production areas investigated. The increase in SOM corresponded to an avoided GHG emission of $118 \mathrm{kt} \mathrm{CO}_{2}$ eq per year, which means a SOM build-up that is more than ten times higher than the loss of SOM resulting from ignoring straw removal restrictions. The impact is lower in the more northerly production areas PA3 and PA4 due to a lower IC yield, but incorporation of the IC root biomass still more than compensates for SOM losses due to unrestricted straw removal in all production areas in the region (Fig. 2).

The variation of the data used for ICB model parameterization is shown in Table 3, but has not been included in the assessment. An evaluation of the impacts of these variations is possible, but would require an increase in data resolution to e.g. municipal level instead of production area level. A more detailed assessment could also include different choices of IC instead of one model IC. A future assessment a feedstock demand of $20000 \mathrm{t}$ DM straw per year. The increased impact of a facility with a feed stock demand of 100000 t DM per year is shown by the dotted orange bar. (Color figure online)

on municipal or field level would give valuable additional information for guidance on for which soils an implementation will result in satisfactory impacts on SOC as compared to the current general straw removal restrictions. Still, the assessment on production area level shown here confirm that the concept of increased straw removal and cultivation of IC as a way of affecting SOC positively is promising.

\section{Greenhouse Gas Emissions}

To allow sustainability assessment from the perspective of an industrial operator, the emissions shown in Fig. 2 were recalculated per unit DM straw. Results are given for two scenarios (Fig. 3):

- Removable: Considering only the straw that is removable when removal restrictions are implemented, $230000 \mathrm{t}$ DM annually in total in the four production areas and

- Unrestricted removal +IC: ignoring the removal restriction and removing the straw that would otherwise have been incorporated into the soil, $560000 \mathrm{t} \mathrm{DM}$ in total, and including IC cultivation as an alternative strategy for SOM conservation. 
Compensation for the nutrients removed in the straw is added, and emissions arising from transport to an industrial facility are included. The net value above the bars include transport emissions for an industrial facility with a feedstock demand of $20000 \mathrm{t}$ DM straw per year. The additional transport demand when the feedstock demand is increased to $100000 \mathrm{t}$ DM per year is shown as Transport: increased demand (dotted orange bar). If no such bar is shown, the region cannot cover the demand of $100000 \mathrm{t}$ DM per year. Where no results are given (removable, PA2), the basic demand of $20000 \mathrm{t}$ DM per year cannot be covered in the production area.

The emissions from straw field operations are negligible. Compensation for the nutrients removed accounts for $37 \mathrm{~kg}$ $\mathrm{CO}_{2}$ eq per $\mathrm{t} \mathrm{DM}$, irrespective of the straw removal strategy. Transport emissions for a $20000 \mathrm{t}$ DM per year facility vary with both region and removal restrictions, from $21 \mathrm{~kg} \mathrm{CO}_{2} \mathrm{eq}$ $(\mathrm{t} \mathrm{DM})^{-1}(\mathrm{PA} 1$, unrestricted removal $+\mathrm{IC})$ to $40 \mathrm{~kg} \mathrm{CO}_{2} \mathrm{eq}(\mathrm{t}$ $\mathrm{DM})^{-1}$ (PA4, removable). Increasing the feedstock demand to $100000 \mathrm{t}$ DM per facility per year increases transport emissions by $25-39 \%$. The emission due to SOM losses with unrestricted straw removal is highest in PA3, $20 \mathrm{~kg} \mathrm{CO}_{2} \mathrm{eq}$ $(\mathrm{t} \mathrm{DM})^{-1}$.

In this study, the straw was regarded as a by-product and it was assumed that the default management practice includes removal restrictions such that part of the straw is incorporated into the soil. Thus, the straw is not burdened by any of the emissions from cereal cultivation, but with the emissions due to SOM degradation. When ignoring the removal restriction (and before including the impact of IC cultivation), the GHG emissions, including transport emissions and emissions due to $\mathrm{SOM}$ degradation, range between 60 (PA1) and 86 (PA4) $\mathrm{kg} \mathrm{CO}_{2}$ eq (t DM straw) $)^{-1}$. Lokesh et al. [5] carried out a study in which the straw was regarded as a co-product from cereal cultivation, and the emissions arising from cultivation were divided between grain and straw, based on economic value (economic allocation) or mass (mass allocation). This approach gave straw GHG emissions of 64-68 $\mathrm{kg} \mathrm{CO}_{2} \mathrm{eq}(\mathrm{t} \mathrm{DM} \text { straw })^{-1}$. These results are in the same range as those in the present study, despite the fact that they were obtained with two completely different methodologies. However, considering the straw to be a co-product does not include or visualize the important aspect of the impact on SOM in the field. These ranges of values can also be compared to the emissions associated with the use of straw for bioenergy applications presented by the EU Joint Research Centre, of 70-170 $\mathrm{kg} \mathrm{CO}_{2} \mathrm{eq}(\mathrm{t} \mathrm{DM})^{-1}$ [43]. These calculations did not include changes in SOM. Instead, the strategy suggested to avoid the negative effects of straw removal on SOM was to implement general removal restrictions, where the removal of $33-50 \%$ of the aboveground straw was defined as sustainable [43]. However, as shown in this study, such general removal restrictions are not generally an efficient measure to maintain soil quality and fertility. The result of ignoring removal restrictions on soil SOM was in this study shown to be negligible in PA1 and PA2, so straw incorporation in these regions would be an unnecessary measure, and an inefficient alibi for SOM preservation in arable land.

The alternative strategy for SOM preservation evaluated in the current study was to combine unrestricted straw removal with IC cultivation. As can be seen in Fig. 2, the net impact on SOM is a significant build-up (here presented as an avoided GHG emission) in all cases. Attributing the whole benefit and emission from IC cultivation to the straw removed will give a net negative value, i.e. the increase in SOM resulting from the IC more than compensates for the total emissions from all straw handling and IC cultivation (Fig. 3).

\section{Costs}

The cost of harvest, baling, transport to the roadside and nutrient compensation are constant irrespective of removal restrictions, and amount to $€ 23$ (t DM) ${ }^{-1}$ (Fig. 3). Neither the farmer's income from the sale of straw nor cost the cost of storage is included. This cost can be compared to estimates of the price of straw at the roadside of $€ 37(t \mathrm{DM})^{-1}$ for the same south Swedish region [22], and the price of straw in-field in Denmark, of €32-40 (t DM) ${ }^{-1}$ [20].

Including transport costs to a $20000 \mathrm{t} \mathrm{DM}$ per year facility will add $€ 26(\mathrm{t} \mathrm{DM})^{-1}(\mathrm{PA} 1$, unrestricted removal $+I C)$ to $€ 48(\mathrm{t} \mathrm{DM})^{-1}$ (PA4, removable). Increasing the feedstock demand to $100000 \mathrm{t}$ DM per facility per year increases the transport cost by $24-38 \%$ (Fig. 3). No cost has been attributed to the loss or gain in SOM, but environmental compensation is available for the cultivation of ICs, which means that the net costs per production area are very similar, irrespective of scenario. For example, the cost per t DM straw in the removable scenarios, supplying $230000 \mathrm{t} \mathrm{DM}$ of straw per year, and unrestricted removal $+I C$ providing $560000 \mathrm{t}$ DM of straw per year, will give nearly the same cost per DM straw removed even when the cost for cultivation of IC is fully attributed to the removed straw (Fig. 3). The total cost of the straw at the factory gate at a larger facility $(100000 \mathrm{t}$ DM per year) was $€ 60(\mathrm{t} \mathrm{DM})^{-1}$ in the removable scenario, where a sufficient amount of straw was only available in PA1. In the scenarios with unrestricted removal $+I C$, three out of the four production areas investigated could supply $100000 \mathrm{t}$ DM straw per year to a cost between $€ 65(\mathrm{t} \mathrm{DM})^{-1}$ (PA1) and $€ 90(\mathrm{t} \mathrm{DM})^{-1}$ (PA4).

For comparison, the cost of straw including transport to a heat and power plant in Denmark has been calculated to be $€ 88-€ 104$ (t DM $)^{-1}$ [20], while straw cost calculations for larger facilities in Sweden, including $30 \mathrm{~km}$ transport, 
storage and nutrient compensation, gave a value of $€ 77$ ( $\mathrm{t}$ $\mathrm{DM})^{-1}$ [72]. The calculated straw costs can also be compared to the price of wood chips, another potential feedstock in emerging biobased industries in Sweden, where the average price, including delivery to large facilities, paid between 2010 and 2019 has been stable at $€ 100(\mathrm{t} \mathrm{DM})^{-1}$ [73].

\section{Conclusions}

Sustainability evaluations for new feedstocks for biobased industries should be based on best current knowledge. General assumptions concerning the benefits of straw soil incorporation on build-up of soil organic matter have resulted in general removal restrictions, where removal of more than half of the aboveground straw is considered unsustainable. However, the results of the current study show that applying general straw removal restrictions, in line with the recommendations in several European studies, did not have the desired effect in the region investigated. In fact, straw soil incorporation had little or no impact on soil organic matter content. The removal restrictions are well-intended, but could prevent the regional implementation of more efficient measures for soil organic matter preservation, such as intermediate crop cultivation. In addition, straw removal restrictions hinder the use of this renewable feedstock in emerging industries in the bioeconomy. The findings of this regional evaluation demonstrate the necessity of taking new knowledge into consideration, and to complement broad general inventories on a European level with region specific and more detailed evaluations.

The results of this study show that $230000 \mathrm{t}$ DM straw per year could be available in southern Sweden when applying straw removal restrictions. Unrestricted straw removal in combination with the cultivation of intermediate crops could provide $560000 \mathrm{t}$ DM straw and 310000 t DM of the intermediate crop, and, at the same time, considerably increase soil organic matter build-up in arable land. The latter strategy avoids the conflicting goals in straw management and provides a large quantity of feedstock with low GHG emissions for emerging biobased industries. The cost differs little from the cost of the straw in the case of restricted removal. It would thus be an affordable strategy for an industrial user to demand that a straw supplier includes intermediate crops in the crop rotation. This would promote the long-term sustainable development of organic matter in agricultural soils also when all harvestable straw is removed from the field.
Author Contributions Both authors contributed to the study conception and design. Material preparation, data collection and analysis was performed by TP for the agriculture and soil carbon modelling sections and by LB for the life cycle assessment. The first draft of the manuscript was written by LB. Both authors read and approved the final manuscript.

Funding Open access funding provided by Lund University. Funding from The Swedish Research Council for Environment, Agricultural Sciences and Spatial Planning for the project "Farm2Furan: Surplus agricultural feedstocks to furanics", from the Swedish Energy Agency for project 45808-1 "Realising biomass supply—farmers' perspectives on straw and short-rotation forestry" and from EU Interreg for the project "Bioeconomy in the South Baltic Area: Biomass-based Innovation and Green Growth" (BioBIGG; project STHB.01.02.00-DK-0086/16) is gratefully acknowledged.

Data Availability All data used in the study is publicly available.

\section{Declarations}

Conflict of interest The authors declare that they have no conflict of interest.

Open Access This article is licensed under a Creative Commons Attribution 4.0 International License, which permits use, sharing, adaptation, distribution and reproduction in any medium or format, as long as you give appropriate credit to the original author(s) and the source, provide a link to the Creative Commons licence, and indicate if changes were made. The images or other third party material in this article are included in the article's Creative Commons licence, unless indicated otherwise in a credit line to the material. If material is not included in the article's Creative Commons licence and your intended use is not permitted by statutory regulation or exceeds the permitted use, you will need to obtain permission directly from the copyright holder. To view a copy of this licence, visit http://creativecommons.org/licenses/by/4.0/.

\section{References}

1. Auersvald, M., Shumeiko, B., Vrtiška, D., Straka, P., Staš, M., Šimáček, P., Blažek, J., Kubička, D.: Hydrotreatment of straw bio-oil from ablative fast pyrolysis to produce suitable refinery intermediates. Fuel 238, 98-110 (2019)

2. Ekman, A., Wallberg, O., Joelsson, E., Börjesson, P.: Possibilities for sustainable biorefineries based on agricultural residues-a case study of potential straw-based ethanol production in Sweden. Appl. Energy 102, 299-308 (2013)

3. Joelsson, E., Erdei, B., Galbe, M., Wallberg, O.: Techno-economic evaluation of integrated first- and second-generation ethanol production from grain and straw. Biotechnol. Biofuels (2016). https ://doi.org/10.1186/s13068-015-0423-8

4. Karlsson, H., Ahlgren, S., Sandgren, M., Passoth, V., Wallberg, O., Hansson, P.-A.: Greenhouse gas performance of biochemical biodiesel production from straw: soil organic carbon changes and time-dependent climate impact. Biotechnol. Biofuels 10, 217 (2017). https://doi.org/10.1186/s13068-017-0907-9

5. Lokesh, K., West, C., Kuylenstierna, J., Fan, J., Budarin, V., Priecel, P., Lopez-Sanchez, J.A., Clark, J.: Environmental impact assessment of wheat straw based alkyl polyglucosides produced using novel chemical approaches. Green Chem. 19(18), 43804395 (2017) 
6. Thorenz, A., Wietschel, L., Stint, D., Tuma, A.: Assessment of agroforestry residue potentials for the bioeconomy in the European Union. J. Clean. Prod. 176, 348-359 (2018)

7. European Parliament and the Council of the European Union: Directive (EU) 2018/2001 of the European Parliament and of the Council of 11 December 2018 on the promotion of the use of energy from renewable sources. Official Journal of the European Union, Publications office of the European Union, Luxembourg (2018)

8. Gnansounou, E.: Coproducts performances in biorefineries: development of claiming-based allocation models for environmental policy. Bioresour. Technol. 254, 31-39 (2018)

9. European Environment Agency: Variations in Topsoil Organic Carbon Content Across Europe. European Environment Agency, Copenhagen (2010)

10. Fernandez-Ugalde, O., Ballabio, C., Lugato, E., Scarpa, S., Jones, A.: Assessment of Changes in Topsoil Properties in LUCAS Samples Between 2009/2012 and 2015 Surveys. EUR 30147 EN. Publications Office of the European Union, Luxembourg (2020)

11. Soilservice - Conflicting demands of land use, soil biodiversity and the sustainable delivery of ecosystem goods and services in Europe, Final report. https://cordis.europa.eu/project/id/211779/ reporting. (2012). Accessed 22 May 2020

12. Lal, R.: Enhancing crop yields in the developing countries through restoration of the soil organic carbon pool in agricultural lands. Land Degrad. Dev. 17(2), 197-209 (2006)

13. Prade, T., Kätterer, T., Björnsson, L.: Including a one-year grass ley increases soil organic carbon and decreases greenhouse gas emissions from cereal-dominated rotations-a Swedish farm case study. Biosyst. Eng. 164, 200-212 (2017)

14. Soil threats in Europe. In: Stolte, J., Tesfai, M., Øygarden, L., Kværnø, S., Keizer, J., Verheijen, F., Panagos, P., Ballabio, C., Hessel, R. (eds.) EUR 27607 EN. Joint Research Centre, Luxemburg (2016)

15. European Comission.: EU Agricultural Outlook for Markets and Income 2019-2030. Directorate-General for Agriculture and Rural Development, Brussels (2019)

16. Monteleone, M., Garofalo, P., Rita, A., Cammerino, B., Libutti, A.: Cereal straw management: a trade-off between energy and agronomic fate. Ital. J. Agron. 10(2), 59-66 (2015)

17. Lal, R.: Soil carbon management and climate change. In: Hartemink, A.E., McSweeney, K. (eds.) Soil Carbon, pp. 339-361. Springer International Publishing, Heidelberg (2014)

18. Hofgaard, I.S., Seehusen, T., Aamot, H.U., Riley, H., Razzaghian, J., Le, V.H., Hjelkrem, A.-G.R., Dill-Macky, R., Brodal, G.: Inoculum potential of Fusarium spp. relates to tillage and straw management in Norwegian fields of spring oats. Front. Microbiol. 7, 556 (2016)

19. Scarlat, N., Martinov, M., Dallemand, J.F.: Assessment of the availability of agricultural crop residues in the European Union: potential and limitations for bioenergy use. Waste Manag. 30, 1889-1897 (2010)

20. Spöttle, M., Alberici, S., Toop, G., Peters, D., Gamba, L., Ping, S., van Steen, H., Bellefleur, D.: Low iLUC Potential of Wastes and Residues for Biofuels. Ecofys Netherlands, Utrecht (2013)

21. Valin, H., Peters, D., van den Berg, M., Frank, S., Havlik, P., Forsell, N., Hamelinck, C.: The Land Use Change Impact of Biofuels Consumed in the EU. Ecofys Netherlands B V, Utrecht (2015)

22. Dees, M., Elbersen, B., Fitzgerald, J., Vis, M., Anttila, P., Forsell, N., Ramirez-Almeyda, J., Garcia, D., Monti, A., Glavonjic, B., Staritsky, I., Verkerk, H., Prinz, R., Leduc, S., Datta, P., Lindner, M., Zudin, S., Höhl, M.: Atlas with Regional Cost Supply Biomas Pontentials for EU28, Western Balkan Countries, Moldavia, Turkey and Ukraine. Chair of Remote Sensing and Landscape Information Systems, Institute of forest sciences, University of Freiburg, Freiburg (2017)
23. Gurría, P., Ronzon, T., Tamosiunas, S., López, R., García Condado, S., Guillén, J., Cazzaniga, N.E., Jonsson, R., Banja, M., Fiore, G., Camia, A.: Biomass Flows in the European Union: The Sankey Biomass Diagram-Towards a Cross-Set Integration of Biomass. Publication office of the European Union, Luxembourg (2017)

24. Prade, T., Björnsson, L., Lantz, M., Ahlgren, S.: Can domestic production of iLUC-free feedstock from arable land supply Sweden's future demand for biofuels? J. Land Use Sci. 12(6), 407-441 (2017)

25. Lantz, M., Prade, T., Ahlgren, S., Björnsson, L.: Biogas and ethanol from wheat grain or straw: is there a trade-off between climate impact, avoidance of iLUC and production cost? Energies 11, 2633 (2018)

26. Whittaker, C., Borrion, A.L., Newnes, L., McManus, M.: The renewable energy directive and cereal residues. Appl. Energy 122, 207-215 (2014)

27. Andrén, O., Kätterer, T.: ICBM: the introductory carbon balance model for exploration of soil carbon balances. Ecol. Appl. 7(4), 1226-1236 (1997)

28. Mattsson, L., Larsson, H.: Att föra bort eller bruka ner halmen påverkar mullhalt, daggmaskar och skadedjur (in Swedish). Swedish University of Agricultural Sciences, Division of Soil Fertility, Uppsala (2005)

29. Kätterer, T., Bolinder, M.A., Andrén, O., Kirchmann, H., Menichetti, L.: Roots contribute more to refractory soil organic matter than above-ground crop residues, as revealed by a long-term field experiment. Agric. Ecosyst. Environ. 141(1-2), 184-192 (2011)

30. Poeplau, C., Kätterer, T., Bolinder, M., Börjesson, G., Berti, A., Lugato, E.: Low stabilization of aboveground crop residue carbon in sandy soils of Swedish long-term experiments. Geoderma 237-238, 246-255 (2015)

31. Menichetti, L., Ekblad, A., Kätterer, T.: Contribution of roots and amendments to soil carbon accumulation within the soil profile in a long-term field experiment in Sweden. Agric. Ecosyst. Environ. 200, 79-87 (2015)

32. Powlson, D.S., Glendining, M.J., Coleman, K., Whitmore, A.P.: Implications for soil properties of removing cereal straw: results from long-term studies. Agron. J. 103(1), 279-287 (2011)

33. Reicosky, D., Evans, S., Cambardella, C., Allmaras, R., Wilts, A., Huggins, D.: Continuous corn with moldboard tillage: residue and fertility effects on soil carbon. J. Soil Water Conserv. 57(5), 277-284 (2002)

34. Molina, J., Clapp, C., Linden, D., Allmaras, R., Layese, M., Dowdy, R., Cheng, H.H.: Modeling the incorporation of corn (Zea mays L.) carbon from roots and rhizodeposition into soil organic matter. Soil Biol. Biochem. 33(1), 83-92 (2001)

35. Peel, M.C., Finlayson, B.L., McMahon, T.: Updated world map of the Köppen-Geiger climate classification. Hydrol. Earth Syst. Sci. 11, 1633-1644 (2007)

36. Eurostat: Crop production in national humidity. Eurostat, the statistical office of the European Union, Luxembourg, Last updated 2020-10-23. http://appsso.eurostat.ec.europa.eu/nui/submitView TableAction.do. Accessed 25 Oct 2020

37. Statistics Sweden: Åkerarealens användning efter kommun och gröda, hektar. År 1981-2017 (in Swedish). Swedish Board of Agriculture, Jönköping, Sweden (2018)

38. Björnsson, L., Prade, T., Lantz, M.: Grass for biogas-arable land as carbon sink. An environmental and economic assessment of carbon sequestration in arable land through introduction of grass for biogas production. Report 2016:280. Energiforsk, Stockholm/ Malmö, Sweden (2016)

39. Prade, T.: Soil organic carbon development in a cereal-dominated region-impact of crop rotation diversification, LCA Food: the 10th international conference on life cycle assessment of food, October 19-21, Dublin, Ireland (2016) 
40. Ministry of the Environment: A Coherent Policy for the Climate. Government offices of Sweden, Stockholm (2019)

41. Markens potential som kolsänka (in Swedish). Nordiska kommittén för jordbruk och matforskning and Samnordisk skogsforskning, Nordic Council, Copenhagen, Denmark (2019)

42. Henriksson, A., Stridsberg, S.: Möjligheter att använda halmeldning till energiförsörjningen i södra Sverige (in Swedish). Department of Agricultural Engineering, Swedish University of Agricultural Sciences, Uppsala (1992)

43. Giuntoli, J., Agostini, A., Edwards, R., Marelli, L.: Solid and Gaseous Bioenergy Pathways: Input Values and GHG Emissions. Calculated According to the Methodology Set in COM(2016) 767. Publications Office of the European Union, Luxembourg (2015)

44. Dees, M., Elbersen, B., Fitzgerald, J., Vis, M., Ramirez-Almeyda, J., Glavonijc, B., Staritsky, I., Verkerk, H., Monti, A., Datta, P., Schrijver, R., Lindner, M., Diepen, K.: Roadmap for Regional End-Users on How to Collect, Process, Store and Maintain Biomass Supply Data. Chair of Remote Sensing and Landscape Information Systems, Institute of forest sciences, University of Freiburg, Freiburg (2017)

45. Statistics Sweden: Odlingsåtgärder i jordbruket 2012. Träda, slåttervall, vårkorn, höstspannmål samt användning av halm och blast (in Swedish). Report 44. Statistics Sweden, Stockholm (2013)

46. Statistics Sweden: Normskördar för skördeområden, län och riket 2016 (in Swedish) Statistics Sweden. Stockholm (2016)

47. Nilsson, D., Bernesson, S.: Halm som bränsle. Del 1: Tillgångar och skördetidpunkter (in Swedish). Department of Energy and Technology, Swedish University of Agricultural Sciences, Uppsala (2009)

48. Hagman, J., Halling, M.A., Dryler, K.: Stråsäd, trindsäd, oljeväxter, potatis-Sortval 2017 (in Swedish). Institutionen för växtproduktionsekologi, Swedish University of Agricultural Sciences, Uppsala (2017)

49. Lantz, M., Kreuger, E., Björnsson, L.: An economic comparison of dedicated crops vs agricultural residues as feedstock for biogas of vehicle fuel quality. AIMS Energy 5(5), 838-863 (2017)

50. Carlsson, G., Mårtensson, L.-M., Prade, T., Svensson, S.-E., Jensen, E.S.: Perennial species mixtures for multifunctional production of biomass on marginal land. GCB Bioenergy 12373 (2016). https://doi.org/10.1111/gcbb.12373

51. Phyllis2, database for (treated) biomass, algae, feedstocks for biogas production and biochar, ECN.TNO. https://phyllis.nl/. Accessed 12 Jan 2021

52. Autret, B., Mary, B., Chenu, C., Balabane, M., Girardin, C., Bertrand, M., Grandeau, G., Beaudoin, N.: Alternative arable cropping systems: a key to increase soil organic carbon storage? Results from a 16 year field experiment. Agric. Ecosyst. Environ. 232, 150-164 (2016)

53. Peltre, C., Nielsen, M., Christensson, B.T., Hansen, E.M., Thomsen, I.K., Bruun, S.: Straw export in continuous winter wheat and the ability of oil radish catch crops and early sowing of wheat to offset soil C and N losses: a simulation study. Agric. Syst. 143, 195-202 (2016)

54. Swedish Board of Agriculture: Skörd av potatis. Statistiska meddelanden (on Swedish). Swedish Board of Agriculture, Jönköping, Sweden (2016)

55. Molinuevo-Salces, B., Larsen, S.U., Ahring, B.K., Uellendahl, H.: Biogas production from catch crops: evaluation of biomass yield and methane potential of catch crops in organic crop rotations. Biomass Bioenergy 59, 285-292 (2013)

56. Dapaah, H.K., Vyn, T.J.: Nitrogen fertilization and cover crop effects on soil structural stability and corn performance. Commun. Soil Sci. Plant Anal. 29(17-18), 2557-2569 (1998)
57. Chahal, I., Van Eerd, L.L.: Cover crop and crop residue removal effects on temporal dynamics of soil carbon and nitrogen in a temperate, humid climate. PLoS ONE 15(7), e0235665 (2020). https://doi.org/10.1371/journal.pone.0235665

58. Asplund, L., Svensson, L.: Ersättning för minskat kväveläckage (in Swedish). In: Hörnsten, C. (ed.) Programmen och pengarna, pp. 215-231. Swedish Board of Agriculture, Jönköping (2018)

59. Swedish Environmental Protection Agency.: National Inventory Report Sweden 2019, Greenhouse Gas Emissions Inventories 1990-2017. Swedish Environmental Protection Agency, Stockholm (2019)

60. Bolinder, M.A., Janzen, H.H., Gregorich, E.G., Angers, D.A., VandenBygaart, A.J.: An approach for estimating net primary productivity and annual carbon inputs to soil for common agricultural crops in Canada. Agric. Ecosyst. Environ. 118(1-4), 29-42 (2007)

61. Sokol, N.W., Bradford, M.A.: Microbial formation of stable soil carbon is more efficient from belowground than aboveground input. Nat. Geosci. 12(1), 46-53 (2019)

62. Persson, J., Kirchmann, H.: Carbon and nitrogen in arable soils as affected by supply of $\mathrm{N}$ fertilizers and organic manures. Agric. Ecosyst. Environ. 51, 249-255 (1994)

63. ISO 14044:2006. Environmental management-Life cycle assessment-Requirements and guidelines. International Organization for Standardization, Geneva, Switzerland (2006)

64. IPCC: Climate Change 2013: The Physical Science Basis. Contribution of Working Group I to the Fifth Assessment Report of the Intergovernmental Panel on Climate Change, Cambridge University Press, Cambridge, United Kingdom and New York, NY, USA (2013)

65. IPCC Guidelines for National Greenhouse Gas Inventories: The Intergovernmental Panel on Climate Change. Institute for Global Environmental Strategies, Kamiyamaguchi Hayama (2006)

66. Drivmedel 2018. Redovisning av rapporterade uppgifter enligt drivmedelslagen, hållbarhetslagen och reduktionsplikten (in Swedish). The Swedish Energy Agency, Eskilstuna (2019)

67. Biograce version 4d, http://www.biograce.net/home (2015)

68. Maskinkostnader 2018 (in Swedish). Maskinkalkylgruppen, Swedish Rural Economy and Agricultural Societies Malmöhus, Bjärred, Sweden (2018)

69. Overend, R.P.: The average haul distance and transportation work factors for biomass delivered to a central plant. Biomass 2, 75-79 (1982)

70. Börling, K., Kvarmo, P., Listh, U., Malgeryd, J., Stenberg, M.: Rekommendationer för gödsling och kalkning 2018 (in Swedish). Swedish Board of Agriculture, Jönköping (2017)

71. S2Biom Tool for biomass chains. Fachagentur Nachwachsende Rohstoffe e.V. (project coordinator), Wageningen Environmental Research (database responsible). https://s2biom.wenr.wur.nl/web/ guest/home (2017), Accessed 28 June 2018

72. Rosenqvist, H.: Kalkyler för energigrödor 2018 (in Swedish). Swedish Board of Agriculture, Jönköping (2018)

73. Trädbränsle och torvpriser, per kvartal exklusive skatt, från och med 1993, kronor/MWh fritt förbrukare, löpande priser (in Swedish). The Swedish Energy Agency, Eskilstuna (2019). http://pxext ernal.energimyndigheten.se/pxweb/sv/Tr\%c3\%a4dbr\%c3\%a4nsl e-\%20och\%20torvpriser/. Accessed 28 Nov 2019

Publisher's Note Springer Nature remains neutral with regard to jurisdictional claims in published maps and institutional affiliations. 


\section{Authors and Affiliations}

\section{Lovisa Björnsson ${ }^{1}$ (D) Thomas Prade ${ }^{2}$ (I)}

Thomas Prade

thomas.prade@slu.se

1 Environmental and Energy Systems Studies, Lund University, P O Box 118, 22100 Lund, Sweden
2 Department of Biosystems and Technology, Swedish University of Agricultural Sciences, P O Box 103,

23053 Alnarp, Sweden 